\title{
'Imposter Syndrome' Holds Back Entrepreneurial Women
}

\author{
Kimberly Eddleston (Northeastern University) \\ Jamie Ladge (Northeastern University) \\ Keimei Sugiyama
}

KEYWORDS: Management of Companies \& Enterprises, Entrepreneurship, Leadership, Women.

The number of businesses run by women continues to grow - by 59\% between 1997 and 2013 - and women now run between a quarter and a third of all private businesses worldwide. Yet their businesses often have fewer assets, grow more slowly and are less profitable than male-owned businesses. Most concerning is how they underplay their achievements, as business owners, compared to men, and their reluctance to call themselves "entrepreneurs."

Why is this happening? Our qualitative interviews suggest that women business owners see the term "entrepreneur" as something beyond their reach and only worthy of the most successful business owners. Further, studies have shown that women business owners struggle more than men because of discrimination from banks, investors, potential business allies and even family members and friends. Some women intentionally limit the size and ambitions of their business in order to free up time and mental space for their relationships, and are happy with that compromise. But others who want to grow get in their own way because of how they see themselves. This has been the focus of our research.

Specifically, we looked at how women business owners were affected by the "imposter phenomenon," which is a tendency to doubt one's abilities and attribute any success to fraud or luck rather than to hard work. Imposters feel that they are not worthy of their position or title, and thus experience much stress because they feel they are acting a part and are not qualified for their position. As a result, the imposter syndrome makes it harder for high-achieving women to internalize their successes and see them as proof of their capabilities. Overcoming this mindset is critical because it limits women's ability to grow their businesses and contribute to their communities and society.

This article presents our research's conclusions and

some suggestions for helping women improve the success of their businesses; the full study can be read here

(https://www.sciencedirect.com/science/article/pii/S000 7681319300710?via\%3Dihub) (https://www.sciencedir ect.com/science/article/pii/S0007681319300710?via\% 3Dihub) .

\section{Roots of the Imposter Syndrome}

One reason why it's easy for women entrepreneurs to suffer from the imposter syndrome is that "entrepreneurship" is typically depicted in masculine terms: "captain of industry," "trailblazer," "pioneer" and others. While the attributes of a successful entrepreneur have historically focused on masculine-sounding traits (ambitious, aggressive, risk-taking and natural born leader), women have been socialized to be nurturing, selfless and collaborative. And despite women's gains in business, society still sees the business world in masculine terms.

For women, these internal and external definitions can make the world of entrepreneurship and business ownership seem alien and at odds with their very identity. People tend to devote the most attention to the roles that feel most at home with their strongest identity. So even if a woman works hard and grows her business, she may see her achievements as a stroke of luck; achievements attained despite her lack of masculine entrepreneurship traits. Rather than gaining confidence from her accomplishments and going on to pursue loftier goals for her business, she may fret that others will soon find out that she really doesn't have "the right stuff." Studies have found that successful women suffer more from imposter fears than do successful men. As a result, men have a self-enhancing bias and women have a self-derogatory bias.

Three factors can make this worse: family demands, 
lack of role models and firm performance. Society demands different things from attentive mothers and working professionals, and women who are taking care of both a business and their families often feel great emotional strain and guilt. They worry that looking too good on the job will make people assume that they lack warmth and that family relationships must be suffering.

Compounding the problem is that few role models exist of women who've excelled in both realms. Research has shown that both men and women look to exemplars in similar roles when they adopt their own behaviors, and having positive role models helps them be more successful. Without these role models, women business owners have a skewed view of their firm's performance: if it does well, they see it as a lucky fluke, and if it's struggling, they see it as a sign that they are in over their heads.

\section{The Remedy: An Alternate Lens}

Changing how women entrepreneurs view their roles and strengths will take time. The business world will likely persist in using masculine attributes to define leadership and successful entrepreneurship. However, studies tend to show that male and female leaders are more similar than different in their traits, thereby suggesting that no "gender advantage" exists in regard to leadership. Where men and women tend to vary is in their views of success and what it takes to attain business goals. As such, women business owners should carve out a new definition of entrepreneurship and business success, one that capitalizes on women's potentially greatest advantages: their emphasis on collaboration and an inspirational, transformational leadership style. Studies have pointed out that female leaders, more than men, have the capacity to gain employees' trust and inspire them. This can also give them an edge with potential investors and customers.

While work-family conflict contributes to the imposter syndrome - especially if the woman entrepreneur feels she must make a dramatic shift from one role to the other - research has shown that women who feel successful in both realms perform better in each. Since a woman entrepreneur can be her own boss, she can build a structure and culture in her company that decreases uncertainty over work-life roles, thus promoting work-life balance among her employees that contributes to their work performance and organizational commitment.
Good mentors and role models can also provide women with perspective on their own performance. Research has shown that women who receive no feedback expect less from themselves than men do, but women and men who receive equal amounts of feedback have the same confidence in themselves. A mentor's feedback can not only reinforce a woman's understanding of her competence and ability as an entrepreneur, but can also make it easier for her to attribute her success to her own capabilities rather than luck.

University-based business and entrepreneurship programs can also play a role in encouraging new definitions of the attributes of successful leaders definitions that give equal value to women's strong suits: team-building, inspirational, transformational attributes. Classes should include case studies of women leaders who built and managed strong businesses, using their own way of leading and carving their own pathways to success. Universities can also play an important role in promoting women's entrepreneurship by conducting research that challenges the old myths and stereotypes of "think entrepreneur, think male."

Additionally, women can subdue imposter syndrome fears by knowing their strengths. A useful exercise in developing this awareness is the "Reflected Best Self." (https://hbr.org/2005/01/how-to-play-to-your-strengths) This exercise provides women with a way to identify and understand their own strengths, while also allowing for women to see their unique background as a strength in understanding their target market. A powerful example is that of the highly successful entrepreneur Bethenny Frankl, who talks about how she uses her perspective asawoman(https://westchestermagazine.com/life-style/ real-housewives-bethenny-frankel-talks-new-bodypositive-denim-line-disaster-relief-efforts/) to tap into her target customers' needs and interests.

While it won't happen overnight, in time these efforts can re-shape how the business world defines successful entrepreneurs, with a new appreciation for uniquely female strengths. More importantly, they can help women business owners shed their imposter syndrome fears and believe in themselves. Women business owners need to take credit for the businesses they have built and proudly refer to themselves as "entrepreneurs." In turn, we can remedy their imposter syndrome fears and inspire the next generation of women looking to start their own businesses. 
Our full study can be read here (https://www.sciencedirect.com/science/article/pii/SO0O 7681319300710?via\%3Dihub) (https://www.sciencedir ect.com/science/article/pii/S0007681319300710?via\% 3Dihub) .

\section{References}

Ahl, H. (2006). Why research on women entrepreneurs needs new directions. Entrepreneurship Theory and Practice, 30(5), 595-621.

Ahl, H., Archer, J., \& Lloyd, B. (2002). Sex and gender. Cambridge, UK: Cambridge University Press.

Ahl, H. J. (2002). The making of the female entrepreneur: A discourse analysis of research texts on women's entrepreneurship (Doctoral dissertation). Jönköping, Sweden: Jönköping University.

American Express. (2013). State of women owned businesses report. Available at https://www.americanexpress.com/us/ smallbusiness/openforum/keywords/state-of-women-ownedbusinesses-report/

Arenius,P., \&Autio,E.(2006).Financing of small businesses: Are Mars and Venus more alike than different? Venture Capital, 8 (2), 93-107.

Ashforth, B. E., Harrison, S. H., \& Corley, K. G. (2008). Identifi cation in organizations: An examination of four fundamental questions. Journal of Management, 34(3), $325-374$.

BarNir, A., Watson, W. E., \& Hutchins, H. M. (2011). Mediation and moderated mediation in the relationship among role models, self-efficacy, entrepreneurial career intention, and gender. Journal of Applied Social Psychology, 41(2), 270-297.

Bar-Tal, D., \& Frieze, I. H. (1977). Achievement motivation for males and females as a determinant of attributions for success and failure. Sex Roles, 3(3), $301-313$.

Bem, S. L. (1974). The measurement of psychological androgyny. Journal of Consulting and Clinical Psychology, 42(2), 155-162.

Bernard, N. S., Dollinger, S. J., \& Ramaniah, N. V. (2002). Applying the big five personality factors to the impostor phenomenon. Journal of Personality
Assessment, 78(2), 321-333.

Blair-Loy, M. (2009). Competing devotions: Career and family among women executives. Cambridge, MA: Harvard University Press.

Brandts, J., Groenert, V., \& Rott, C. (2014). The impact of advice on women's and men's selection into competition. Management Science, 61(5), 1018-1035.

Bruni, A., Gherardi, S., \& Poggio, B. (2004). Entrepreneur-mentality, gender, and the study of women entrepreneurs. Journal of Organizational Change Management, 17(3), 256-268.

Brush, C. G. (1992). Research on women business owners: Past trends, a new perspective, and future directions. Entrepreneurship Theory and Practice, 16(4), 5-30.

Cardon, M. S., Wincent, J., Singh, J., \& Drnovsek, M. (2009). The nature and experience of entrepreneurial passion. Academy of Management Review, 34(3), $511-532$.

Carter, N., Brush, C., Greene, P., Gatewood, E., \& Hart, M. (2003). Women entrepreneurs who break through to equity financing: The influence of human, social, and financial capital. Venture Capital: An International Journal of En- trepreneurial Finance, 5(1), 1-28.

Chrisman, J. J., Hynes, T., \& Fraser, S. (1995). Faculty entrepreneurship and economic development: The case of the University of Calgary. Journal of Business Venturing, 10(4), 267-281.

Clance, P. R., Dingman, D., Reviere, S. L., \& Stober, D. R. (1995). Impostor phenomenon in an interpersonal/social context: Origins and treatment. Women and Therapy, 16(4), 79—96.

Clance, P. R., \& Imes, S. A. (1978). The imposter phenomenon in high achieving women: Dynamics and therapeutic intervention. Psychotherapy: Theory, Research, and Practice, 15(3), 241-247.

Am I an entrepreneur? How imposter fears hinder women entrepreneurs' business growth 623

Cliff, J. E. (1998). Does one size fit all? Exploring the relationship between attitudes towards growth, gender, and business size. Journal of Business Venturing, 
13(6), 523-542.

Coleman, S., \& Robb, A. (2009). A comparison of new firm financing by gender: Evidence from the Kauffman Firm Survey data. Small Business Economics, 33(4), 397-411.

Cowman, S. E., \& Ferrari, J. R. (2002). "Am I for real?" Predicting impostor tendencies from self-handicapping and affective components. Social Behavior and Personality: An Interna- tional Journal, 30(2), 119-125.

Cuddy, A. J., Fiske, S. T., \& Glick, P. (2004). When professionals become mothers, warmth doesn't cut the ice. Journal of Social Issues, 60(4), 701-718.

Davis, A. E., \& Shaver, K. G. (2012). Understanding gendered variations in business growth intentions across the life course. Entrepreneurship Theory and Practice, 36(3), 495-512.

de Bruin, A., Brush, C. G., \& Welter, F. (2006). Introduction to the special issue: Towards building cumulative knowledge on women's entrepreneurship. Entrepreneurship Theory and Practice, 30(5), 585-593.

DeMartino, R., \& Barbato, R. (2003). Differences between women and men MBA entrepreneurs: Exploring family flexibility and wealth creation as career motivators. Journal of Business Venturing, 18(6), 815-832.

de Vries, M. F. R. K. (1990). The organizational fool: Balancing a leader's hubris. Human Relations, 43(8), 751-770.

de Vries, M. F. R. K. (2005). The dangers of feeling like a fake. Harvard Business Review, 83(9), 108-116.

Duguid, M. M., \& Thomas-Hunt, M. C. (2015). Condoning stereo typing? How awareness of stereotype prevalence impacts expressions of stereotypes. Journal of Applied Psychology, 100(2), 343-359.

Eagly, A. H. (2007). Female leadership advantage and disadvantage: Resolving the contradictions. Psychology of Women Quarterly, 31(1), 1-12.

Eagly, A. H., Johannesen-Schmidt, M. C., \& van Engen, M. L. (2003). Transformational, transactional, and laissez-faire leadership styles: A meta-analysis comparing women and men. Psychological Bulletin, 129(4), 569-591.

Eagly, A. H., \& Karau, S. J. (2002). Role congruity theory of prejudice toward female leaders. Psychological Review, 109 (3), 573-598.

Eagly, A. H., Makhijani, M. G., \& Klonsky, B. G. (1992). Gender and the evaluation of leaders: A meta-analysis. Psychological Bulletin, 111(1), 3-22.

Eagly, A. H., Wood, W., \& Diekman, A. B. (2000). Social role theory of sex differences and similarities: A current apprai- sal. In T. Eckes \& H. M. Trautner (Eds.), The developmental social psychology of gender (pp. 123-174). Mahwah, $\mathrm{NJ}$ : Lawrence Erlbaum Associates.

Eddleston, K. A., Ladge, J. J., Mitteness, C., \& Balachandra, L. (2016). Do you see what I see? Signaling effects of gender and firm characteristics on financing entrepreneurial ventures. Entrepreneurship Theory and Practice, 40(3), 489—514.

Eddleston, K. A., \& Powell, G. N. (2008). The role of gender identity in explaining sex differences in business owner's career satisfier preferences. Journal of Business Venturing, 23(2), 244-256.

Erdwins, C. J., Buffardi, L. C., Casper, W. J., \& O'Brien, A. S. (2001). The relationship of women's role strain to social support, role satisfaction, and self-efficacy. Family Relations, 50(3), 230-238.

Fagenson, E. A., \& Marcus, E. C. (1991). Perceptions of the sex role stereotypic characteristics of entrepreneurs: Women's evaluations. Entrepreneurship Theory and Practice, 15(4), 33-48.

Farmer, S. M., Yao, X., \& Kung-Mcintyre, K. (2011). The behavioral impact of entrepreneur identity aspiration and prior entrepreneurial experience. Entrepreneurship Theory and Practice, 35(2), 245-273.

Feather, N. T. (1969). Attribution of responsibility and valence of success and failure in relation to initial confidence and task performance. Journal of Personality and Social Psychology, 13(2), 129-144.

Fischer, E. M., Reuber, A. R., \& Dyke, L. S. (1993). A theoretical overview and extension of research on sex, gender, and entre- preneurship. Journal of Business 
Venturing, 8(2), 151-168.

Foschi, M. (2000). Double standards for competence: Theory and research. Annual Review of Sociology, 26, $21-42$.

Gecas, V. (1982). The self-concept. Annual Review of Sociology, 8, 1-33.

Gibson, D. E. (2003). Developing the professional selfconcept: Role model construals in early, middle, and late career stages. Organization Science, 14(5), $591-610$.

Good, L. R., \& Good, K. C. (1973). An objective measure of the motive to avoid success. Psychological Reports, 33(3), 1009-1010.

Greene, P. G., Brush, C. G., Hart, M. M., \& Saparito, P. (2001). Patterns of venture capital funding: Is gender a factor?

Venture Capital: An International Journal of Entrepreneurial Finance, 3(1), 63-83.

Greenhaus, J. H., \& Powell, G. N. (2006). When work and family are allies: A theory of work-family enrichment. Academy of Management Review, 31(1), 72-92.

Gupta, V. K., Turban, D. B., \& Pareek, A. (2013). Differences between men and women in opportunity evaluation as a function of gender stereotypes and stereotype activation. Entrepreneurship Theory and Practice, 37(4), 771-788.

Gupta, V. K., Turban, D. B., Wasti, S. A., \& Sikdar, A. (2009). The role of gender stereotypes in perceptions of entrepreneurs and intentions to become an entrepreneur. Entrepreneurship Theory and Practice, 33(2), 397-417.

Hall, D. (2002). Brand development, tourism, and national identity: The re-imaging of former Yugoslavia. The Journal of Brand Management, 9(4), 323-334.

Hall, D. T., \& Chandler, D. E. (2005). Psychological success: When the career is a calling. Journal of Organizational Behavior, 26 (2), 155-176.

Harrington, B., \& Hall, D. T. (2007). Career management and work-life integration: Using self- assessment to navigate contemporary careers. Thousand Oaks, CA: Sage.

Helgesen, S. (1990). The female advantage: Women's ways of leading. New York, NY: Doubleday.

Hemingway, C. A. (2005). Personal values as a catalyst for corporate social entrepreneurship. Journal of Business Ethics, 60(3), 233-249.

Hoang, H., \& Gimeno, J. (2010). Becoming a founder: How founder role identity affects entrepreneurial transitions and persistence in founding. Journal of Business Venturing, 25(1), 41-53.

Holcomb, B. (2000). Not guilty! The good news for working mothers. New York, NY: Simon \& Schuster.

Horner, M. S. (1968). Sex differences in achievement motivation and performance in competitive and noncompetitive situations (Doctoral dissertation). Ann Arbor, MI: University of Michigan.

Hughes, K. D., Jennings, J. E., Brush, C., Carter, S., \& Welter, F. (2012). Extending women's entrepreneurship research in new directions. Entrepreneurship Theory and Practice, 36(3), 429—442.

Hytti, U. (2005). New meanings for entrepreneurs: From risk- taking heroes to safe-seeking professionals. Journal of Organizational Change Management, 18(6), 594-611.

\section{J. Ladge et al.}

Ibarra, H. (1999). Provisional selves: Experimenting with image and identity in professional adaptation. Administrative Science Quarterly, 44(4), 764-791.

Imes, S. W. (1979). The impostor phenomenon as a function of attribution patterns and internalized femininity/masculinity in high achieving women and men. Atlanta, GA: Georgia State University.

Jennings, J. E., \& Brush, C. G. (2013). Research on women entrepreneurs: Challenges to (and from) the broader entrepreneurship literature. The Academy of Management Annals, 7(1), 663-715.

Jones, K., \& Tullous, R. (2002). Behaviors of preventure entrepreneurs and perceptions of their financial needs. Journal of Small Business Management, 40(3), 
$233-248$.

Kelly, D. J., Brush, C. G., Greene, P. G., \& Litovsky, Y. (2011). GEM 2010 women's report. Babson Park, MA: Babson College. Kolligian, J., Jr., \& Sternberg, R. J. (1991). Perceived fraudulence in young adults: Is there an 'imposter syndrome'?

Journal of Personality Assessment, 56(2), 308-326. Kossek, E. E., Lewis, S., \& Hammer, L. (2010). Worklife initiatives and organizational change: Overcoming mixed messages to move from the margin to the mainstream. Human Relations, 63(1), 3-19.

Krueger, N. F. (2007). What lies beneath? The experiential essence of entrepreneurial thinking. Entrepreneurship Theory and Practice, 31(1), 123-138.

Ladge, J. J., \& Greenberg, D. (2015). Becoming a working mother: Managing identity and efficacy uncertainties during resocialization. Human Resource Management, 54(6), 977-998.

Ladge, J. J., Humberd, B. K., \& Eddleston, K. A. (2018). Retaining professionally employed new mothers: The importance of maternal confidence and workplace support to their intent to stay. Human Resource Management, 57(4), 883-900. Leary, M. R., Patton, K. M., Orlando, A. E., \& Wagoner Funk, W. W. (2000). The impostor phenomenon: Self-perceptions, reflected appraisals, and interpersonal strategies. Journal of Personality, 68(4), 725-756.

Levine, R., Gillman, M. J., \& Reis, H. (1982). Individual differences for sex differences in achievement attributions. Sex Roles, 8(4), 455-466.

Lippa, R. A. (2005). Gender, nature, and nurture. Abingdon, UK: Routledge.

Loscocco, K., \& Bird, S. R. (2012). Gendered paths: Why women lag behind men in small business success. Work and Occupations, 39(2), 183-219.

Loscocco, K., \& Smith-Hunter, A. (2004). Women homebased business owners: Insights from comparative analyses. Women in Management Review, 19(3), 164-173.

Loscocco, K. A., Robinson, J., Hall, R. H., \& Allen, J. K. (1991). Gender and small business success: An inquiry into women's relative disadvantage. Social Forces, 70(1), 65-85.

Louis, M. R. (1980). Surprise and sense making: What newcomers experience in entering unfamiliar organizational settings. Administrative Science Quarterly, 25(2), 226-251.

MacNeil, N. (2012, June 8). Entrepreneurship is the new women's movement. Forbes. Available at http://www.forbes.com/ progress/2012/06/08/entrepreneurship is-the-newwomens-movement/

McCarty, P. A. (1986). Effects of feedback on the selfconfidence of men and women. Academy of Management Journal, 29(4), 840-847.

Menzies, T. V., Diochon, M., \& Gasse, Y. (2004). Examining venture-related myths concerning women entrepreneurs. Journal of Developmental Entrepreneurship, 9(2), 89-107.

Morris, M. H., Miyasaki, N. N., Watters, C. E., \& Coombes, S. M. (2006). The dilemma of growth: Understanding venture size choices of women entrepreneurs. Journal of Small Business Management, 44(2), $221-244$.

Murnieks, C., Mosakowski, E., \& Cardon, M. (2014). Pathways of passion: Identity centrality, passion, and behavior among entrepreneurs. Journal of Management, 40(6), 1583-1606.

Murphy, P. J., Kickul, J., Barbosa, S. D., \& Titus, L. (2007). Expert capital and perceived legitimacy: Femalerun entrepreneurial venture signaling and performance. The International Journal of Entrepreneurship and Innovation, 8(2), 127-138.

Navis, C., \& Glynn, M. A. (2011). Legitimate distinctiveness and the entrepreneurial identity: Influence on investor judgments of new venture plausibility. Academy of Management Review, 36(3), 479-499.

Powell, G. N. (2011). The gender and leadership wars. Organizational Dynamics, 40(1), 1-9.

Powell, G. N., \& Eddleston, K. A. (2008). The paradox of the contented female business owner. Journal of Vocational Behavior, 73(1), 24-36. 
Powell, G. N., \& Eddleston, K. A. (2013). Linking familyto- business enrichment and support to entrepreneurial success: Do female and male entrepreneurs experience different out- comes? Journal of Business Venturing, 28(2), $261-280$.

Renn, R. W., Allen, D. G., Fedor, D. B., \& Davis, W. D. (2005). The roles of personality and self-defeating behaviors in self-management failure. Journal of Management, 31(5), 659—679.

Ridgeway, C. L. (2001). Gender, status, and leadership. Journal of Social Issues, 57(4), 637-655.

Ridgeway, C. L., \& Correll, S. J. (2004). Unpacking the gender system: A theoretical perspective on gender beliefs and social relations. Gender and Society, 18(4), $510-531$.

Roberts, L. M., Spreitzer, G., Dutton, J., Quinn, R., Heaphy, E., \& Barker, B. (2005). How to play to your strengths. Harvard Business Review, 83(1), 74-80.

Rosener, J. B. (1990). Ways women lead. Harvard Business Review, 68(6), 119-125.

Rothbard, N. P., \& Edwards, J. R. (2003). Investment in work and family roles: $A$ test of identity and utilitarian motives. Personnel Psychology, 56(3), 699-729.

Ruble, D. N., \& Martin, C. L. (1998). Gender development. In W. Damont \& S. Eisenberger (Eds.), Handbook of child psychology: Social, emotional, and personality development (pp. 933-1016). Hoboken, $\mathrm{NJ}$ : Wiley.

Schein, E. H. (1978). Career dynamics: Matching individual and organizational needs (Vol. 24). Reading, MA: Addison-Wesley. Schumpeter, J. A. (1934/1989). Change and the entrepreneur. Essays: On entrepreneurs, innovations, business cycles, and

the evolution of capitalism. Abingdon, UK: Routledge. Shepherd, D., \& Haynie, J. M. (2009). Family business, identity conflict, and an expedited entrepreneurial process: A process of resolving identity conflict. Entrepreneurship Theory and

Practice, 33(6), 1245-1264.

Sightler, K. W., \& Wilson, M. G. (2001). Correlates of the impostor phenomenon among undergraduate entrepreneurs. Psychological Reports, 88(3), 679—689.

Simon, J. G., \& Feather, N. T. (1973). Causal attributions for success and failure at university examinations. Journal of Educational Psychology, 64(1), $46-56$.

Stryker, S. (1989). Further developments in identity theory: Singularity versus multiplicity of self. In $\mathrm{J}$. Berger, M., Zelditch, Jr., \& B. Anderson (Eds.), Sociological theories in progress: New formulations (pp. 35-57). Thousand Oaks, CA: Sage.

Verheul, I., Uhlaner, L., \& Thurik, R. (2005). Business accomplishments, gender, and entrepreneurial selfimage. Journal of Business Venturing, 20(4), 483-518.

Wilson, F., Kickul, J., \& Marlino, D. (2007). Gender, entrepreneurial self-efficacy, and entrepreneurial career intentions: Implications for entrepreneurship education. Entrepreneurship Theory and Practice, 31(3), 387-406.

Additional search terms: feminism, female founders, women business owners, glass ceiling, sexual discrimination, sexual harassment, bias, opportunity 